\author{
Marquette University \\ e-Publications@Marquette
}

School of Dentistry Faculty Research and

Publications

Dentistry, School of

3-2018

\title{
The Post-endodontic Adhesive Interface: Theoretical Perspectives and Potential Flaws
}

Georgios Maroulakos

Marquette University, georgios.maroulakos@marquette.edu

Jianing $\mathrm{He}$

Texas A\&M University College of Dentistry

William W. Nagy

Texas A\&M University College of Dentistry

Follow this and additional works at: https://epublications.marquette.edu/dentistry_fac

Part of the Dentistry Commons

\section{Recommended Citation}

Maroulakos, Georgios; He, Jianing; and Nagy, William W., "The Post-endodontic Adhesive Interface:

Theoretical Perspectives and Potential Flaws" (2018). School of Dentistry Faculty Research and

Publications. 288.

https://epublications.marquette.edu/dentistry_fac/288 
Marquette University

e-Publications@Marquette

\section{Dentistry Faculty Research and Publications/School of Dentistry}

This paper is NOT THE PUBLISHED VERSION; but the author's final, peer-reviewed manuscript. The published version may be accessed by following the link in the citation below.

Journal of Endodontics, Vol. 44, No. 3 (March, 2018): 363-371. DOI. This article is @ Elsevier and permission has been granted for this version to appear in e-Publications@Marquette. Elsevier does not grant permission for this article to be further copied/distributed or hosted elsewhere without the express permission from Elsevier.

\section{The Post-endodontic Adhesive Interface: Theoretical Perspectives and Potential Flaws}

Georgios Maroulakos

Department of General Dental Sciences, Marquette University School of Dentistry, Milwaukee, Wisconsin

Jianing $\mathrm{He}$

Department of Endodontics, Texas A\&M University College of Dentistry, Dallas, Texas William W. Nagy

Department of Restorative Sciences, Texas A\&M University College of Dentistry, Dallas, Texas

\section{Abstract \\ Introduction}

The aim of this review was to analyze the potential of successful bonds of endodontic posts to radicular dentin as well as the limitations of the post-endodontic adhesive interface. 


\section{Methods}

The MEDLINE/PubMed and Web of Science electronic databases were searched. The search was augmented by a manual search of the pertinent bibliographies.

\section{Results}

The post-endodontic adhesive interface finds application in the endodontic cohesive units. Many techniques and materials exist to improve the bond between endodontic posts and resinbased materials as well as between resin-based materials and radicular dentin. Different techniques used for the adhesion of metallic and fiber-reinforced posts are discussed and critically analyzed.

\section{Conclusions}

Although adhesive cementation of endodontic posts is popular, a long-term predictable bond may be compromised because of procedures related to the endodontic treatment and/or the adhesive cementation procedures. Microleakage and degradation phenomena may further jeopardize the post-endodontic adhesive interface.

Key Words

Adhesion; endodontic dowel; endodontic post; radicular dentin; resin cement

\section{Significance}

Although adhesive cementation of endodontic posts is popular, long-term predictable bonds may be compromised because of procedures related to the endodontic treatment and/or the adhesive cementation procedures. Microleakage and degradation phenomena may further jeopardize the post-endodontic adhesive interface.

Adhesive cementation of intraradicular posts has become a popular treatment modality. Traditionally, the purpose of the cement is to fill the gaps between the prepared post space and the post. The main retentive value of the post is provided by the geometric characteristics of the post and the properties of the cement 1 , 2. However, the development of resin cements significantly expanded the role cements play. Resin cements exhibit a higher number of cycles to preliminary failure ${ }^{(3)}$ and better retention $4, \underline{5}, \underline{6}, \underline{7}$, even if the post has a reduced length $\underline{8}, \underline{9}$. They also appear to be the most suitable for the cementation of fiber posts $\underline{6}, \underline{10}$, $\underline{11}$. Finally, there is some evidence that the use of resin cements may increase the fracture resistance of teeth restored with a cast post and core $\frac{(12)}{\text {. }}$.

The post-endodontic adhesive interface is 1 of the interfaces that form the cohesive endodontic units or "monoblocks." The "cohesive endodontic unit" model is based on the idea that a strong bond could be achieved among radicular dentin, post, and foundation core material $\stackrel{(13)}{ }$. Also, the different materials would have similar flexural properties $\underline{(13)}$. As a result, 
they function cohesively and not as a mechanically heterogeneous unit $\frac{(14)}{2}$. The term "monoblock" is a misnomer because it refers to structures made from 1-piece materials, and as such it cannot describe a multi-interface adhesive system accurately. Monoblocks have been further classified into primary, secondary, and tertiary based on the number of the different existing interfaces $\frac{(13)}{12}$. This model was first described with the adhesive cementation of fiber posts using resin cements and the bonding of foundation core composite resin materials to the post and the remaining dentin. However, adhesive cementation could also be achieved today using metallic posts $(15)$. This review aims to discuss the potential of achieving a predictable bond between different post materials and dental substrates as well as the possible limitations that may lead to failure of the post-endodontic adhesive interface.

\section{Literature Search Strategy}

An online search of the literature was conducted using the MEDLINE/PubMed and Web of Science databases. The key words used to search the electronic databases were combinations of the following: "endodontic post" OR "endodontic dowel," "adhesion" OR "bonding," "resin cement" OR "composite resin," "dentin," "metals" OR "alloys," "surface treatment," and "monoblock." The search results were limited to articles published in English since 1980. Additionally, the following journals were manually searched to identify relevant articles: Journal of Endodontics, Journal of Prosthetic Dentistry, and Journal of Prosthodontics. Inclusion criteria for full-text review were that the selected articles should investigate or discuss the bonding of composite resin-based products to various types of endodontic post materials and dentin.

Results

After duplicate articles were removed, titles and abstracts were reviewed to select relevant articles. Because of the nature of the search, a variety of article types were included, such as systematic reviews, narrative reviews, and in vitro studies. No clinical studies were identified. A total of 66 articles were identified that were related to the aim of this review. Articles that provided additional relevant information but were not related to bonding of endodontic posts to radicular dentin were also included to provide a more complete review of the materials and techniques described, bringing the total number of articles to 118 . The articles were subsequently organized into the following topics: bond to fiber-reinforced posts, bond to metallic posts, bonds to radicular dentin, and microleakage and degradation phenomena.

\section{Discussion}

\section{Bond to Fiber-reinforced Posts}

Fiber-reinforced posts consist of fibers (glass, carbon, quartz, or polyethylene) embedded in a polymer-epoxy resin matrix. The purpose of the fibers is to increase the tensile and fatigue strength of the post and to enhance its volumetric stability. The epoxy matrix is highly crosslinked, with a very high degree of polymerization conversion. Its purpose is to support and 
protect the fibers $\frac{(16)}{2}$. The most common technical complication of endodontically treated teeth restored with fiber posts is post debonding $\underline{17}, \underline{18}$. Interpenetration between resins and the fiber post material is feasible in products with an intrapolymer network-polymer matrix (ie, everStick Post [GC America Inc, Alsip, IL]) ${ }^{(19)}$. This is consistent with the absence of adhesive failures of post systems with an intrapolymer network-polymer matrix $\stackrel{(20)}{2}$. The direction of the fibers can be longitudinal or vertical and is product dependent. Longitudinal fibers may allow for a better bond with the tooth, resin cement, and foundation core material (21). However, when the fibers are vertically oriented, the post generally has superior mechanical properties, increased stiffness, fatigue, and fracture resistance $\stackrel{(22)}{2}$. The high degree of polymerization conversion of the resin matrix in fiber posts may result in a poor bond between resin cements and the post surface because of the lack of free functional groups $\stackrel{(23)}{2}$. Adhesion to the fiber post surface is significantly inferior to dental substrates $\underline{(24)}$.

Many techniques suggest modification or treatment of the post surface to increase the adhesion of resin cements. These techniques include, but are not limited to, the application of hydrofluoric acid $\underline{(25)}$, phosphoric acid $\underline{(26)}$, hydrogen peroxide $\underline{27}, \underline{28}, \underline{29}, \underline{30}, \underline{31}$, methylene chloride $\underline{(29)}$, potassium permanganate $\stackrel{(28)}{ }$, silane $\underline{25}, \underline{27}, \underline{28}, \underline{29}, \underline{31}, \underline{32}, \underline{33}, \underline{34}, \underline{35}, \underline{36}, \underline{37}, \underline{38}, \underline{39}, \underline{40}$, tribochemical coating systems $\underline{25}, \underline{39}$, and airborne-particle abrasion $\underline{26}, \underline{35}, \underline{36}$. Surface conditioning of fiber posts with silane, tribochemical coating, phosphoric acid, hydrofluoric acid, or potassium permanganate is not always effective $\underline{25}, \underline{26}, \underline{2}, \underline{32}, \underline{34}, \underline{37}$, $\underline{40}$. Silane could increase the bond strength, but a fiber post may have no free functional groups to react with silane $\stackrel{(41)}{ }$. However, silane could be effective when it follows other post pretreatment techniques $\underline{25}, \underline{42}$. Hydrogen peroxide functions through dissolution of the epoxy resin matrix and appears to be more effective when compared with methylene chloride ${ }^{(29)}$. Hydrogen peroxide is also more effective

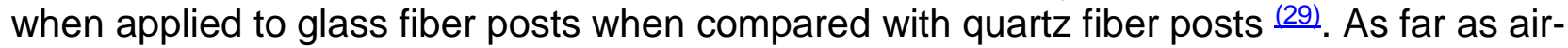
particle abrasion is concerned, it could increase the retention of resin on the surface of fiber posts $(36)$. Air-particle abrasion causes partial removal of the epoxy resin matrix that exposes the fibers, increases the available surface area, and increases the surface roughness of the fiber posts $\frac{(35)}{3}$. Subsequently, resins could interact through micromechanical interlocking and slide friction $(36)$. Whether this method increases post retention and bonding is controversial $\underline{26}$, 35 , 36 . Nevertheless, it is generally agreed that even though air-particle abrasion may increase bond strengths it may be an aggressive procedure that can alter the morphologic characteristics and the properties of the fiber posts $\underline{35}, \underline{36}$. Therefore, its application cannot be safely recommended for all fiber post systems. Thus, all the techniques previously described are highly material dependent, and there is no sound scientific basis for their predictable universal application on all fiber-reinforced posts.

\section{Bond to Metallic Posts}

Metallic posts, prefabricated or custom, can be fabricated from high noble alloys or various types of base metal alloys (nickel-chromium alloys, stainless steel, and titanium). A resinbased material could bond to a metal oxide layer through hydrophilic bonds. However, this bond is relatively weak and prone to hydrolysis $\stackrel{(43)}{ }$. Techniques attempting to enhance the bond quality between metal surfaces and resin-based materials can be mainly divided into 2 categories: surface modification techniques and techniques involving the application of primers containing functional monomers. 
Surface modification techniques include pyrochemical silica coating techniques $(44)$,

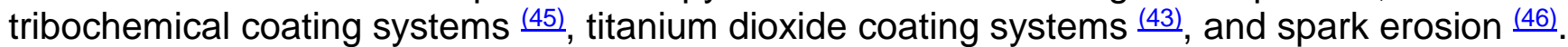
These techniques create a silicified oxide layer on the metal surface that could lead to a predictable bond with resin-based materials. The tinplate technique could also be added in this category, increasing the bond strength of composite resins to noble alloys through the

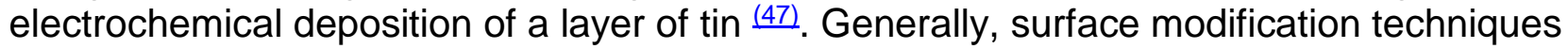

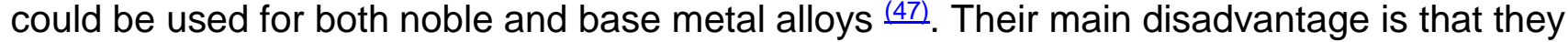
are more complicated procedures and require special equipment. Also, they cannot be easily applied chairside.

Functional monomers contain groups of atoms or bonds that are responsible for a specific chemical reaction. These functional monomers have a chemical affinity to metals and concurrently copolymerize with the structural monomers of resin-based materials. Primers containing functional monomers can be further divided into primers for base metal alloys/titanium, primers for noble alloys, and universal primers. Base metal alloy primers include functional monomers that contain phosphate or carboxylic acid functional groups (48). Examples include 10-methacryloyloxydecyl dihydrogen phosphate and 4-methacryloyloxyethyl trimellitate anhydride, which create an ionic bond with resin-based products $\stackrel{(48)}{\mathrm{e}}$. The application of 10-methacryloyloxydecyl dihydrogen phosphate results in a better bond than 4methacryloyloxyethyl trimellitate anhydride when applied on nickel-chromium alloys $\stackrel{(49)}{50}$. It forms its most predictable bond with commercially pure titanium and titanium alloys $\underline{50}, \underline{51}, \underline{52}, \underline{53}$. Noble metal alloy primers include functional monomers that contain thionic groups. An example is 6-(4-vinylbenzyl-n-propyl) amino 1,3,5-triazine-2,4-dithiol, dithione tautomer, which also creates an ionic bond ${ }^{(54)}$. Finally, the universal primers consist of a combination of

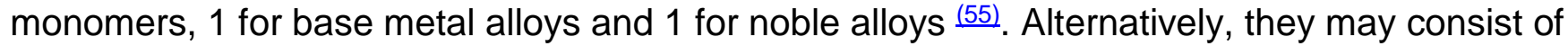
dual functional monomers, which contain both phosphate and thionic functional groups in a single molecule ${ }^{(56)}$. An example is thiophosphate methacryloyloxyalkyl. The main advantage of the universal primers is that only 1 primer is necessary and can be applied to any kind of alloy. Examples of the metal primer products currently available are listed in Table 1.

Table 1. Examples of Available Primers for Bonding Resin-based Materials to Metal Surfaces

\begin{tabular}{|c|c|c|c|}
\hline Product & Functional monomers & Use & Manufacturer \\
\hline ALLOY PRIMER & 10-MDP/VBATDT & Universal & $\begin{array}{l}\text { Kuraray America Inc, } \\
\text { Houston, TX }\end{array}$ \\
\hline Futurabond $\mathrm{M}+$ & Proprietary & Universal & $\begin{array}{l}\text { VOCO America Inc, Indian } \\
\text { Land, SC }\end{array}$ \\
\hline $\begin{array}{l}\text { GC } \\
\text { METALPRIMER II }\end{array}$ & MEPS & Universal & GC America Inc, Alsip, IL \\
\hline META FAST & 4-META & $\begin{array}{l}\text { Noble } \\
\text { alloys }\end{array}$ & $\begin{array}{l}\text { Sun Medical Co Ltd, } \\
\text { Moriyama, Japan }\end{array}$ \\
\hline METALTITE & MTU-6 & $\begin{array}{l}\text { Noble } \\
\text { alloys }\end{array}$ & $\begin{array}{l}\text { Tokuyama Dental America } \\
\text { Inc, Encinitas, CA }\end{array}$ \\
\hline
\end{tabular}




\begin{tabular}{|c|c|c|c|}
\hline Product & Functional monomers & Use & Manufacturer \\
\hline M.L. Primer & 10-MDDT/6-MHPA & Universal & $\begin{array}{l}\text { Shofu Dental Corporation, } \\
\text { San Marcos, CA }\end{array}$ \\
\hline Monobond Plus & $\begin{array}{l}\text { Methacrylated phosphoric acid } \\
\text { ester/proprietary }\end{array}$ & Universal & $\begin{array}{l}\text { Ivoclar Vivadent Inc, } \\
\text { Amherst, NY }\end{array}$ \\
\hline MTL-V Primer & Proprietary & $\begin{array}{l}\text { Noble } \\
\text { alloys }\end{array}$ & Parkell Inc, Edgewood, NY \\
\hline V-PRIMER & VTD & $\begin{array}{l}\text { Noble } \\
\text { alloys }\end{array}$ & $\begin{array}{l}\text { Sun Medical Co Ltd, } \\
\text { Moriyama, Japan }\end{array}$ \\
\hline Z-Prime Plus & 10-MDP/proprietary & Universal & Bisco Inc, Schaumburg, IL \\
\hline
\end{tabular}

4-META, 4-methacryloyloxyethyl trimellitate anhydride; 10-MDDT, 10-methacryloyloxydecyl-6,6dithiooctanate; MDP, 10-methacryloyloxydecyl dihydrogen phosphate; MEPS, thiophosphate methacryloyloxyalkyl; MTU-6, 6-methacryloyloxyhexyl 2-thiouracil-5-carboxylate; 6-MHPA, 6methacryloyloxyhekyl phosphonoacetate; VBATDT, 5-(4-vinylbenzyl)-2-thiobarbituricacid (5VS), 6- (4vinylbenzyl-n-propyl) amino-1,3,5-triazine-2,4-dithione; VTD, 6-(4-vinylbenzyl-n-propyl) amino 1,3,5triazine-2,4-dithiol, dithione tautomer.

Air-particle abrasion with aluminum oxide $\left(\mathrm{Al}_{2} \mathrm{O}_{3}\right)$ particles is necessary for the primers to be effective. The principal mechanism is not clear, but it may act through an increase of the surface area (micromechanical retention), a decrease of surface tension (adhesion and wettability), and/or oxidization of base metal alloys (chemical bond) $\underline{49}, \underline{56}, \underline{57}$. However, airparticle abrasion may alter the character of the metal surface. Aluminum oxide particles may get trapped and partially cover the original alloy elements in the superficial layer ${ }^{(58)}$. The chemical affinity of aluminum particles to phosphate monomers may be responsible for the improved performance of some primers after air-particle abrasion $\stackrel{(49)}{ }$.

\section{Bond to Radicular Dentin}

Bonding to dentin is considered a predictable clinical procedure. Traditionally, this could be achieved by etching the dentin and applying a primer and an adhesive. Etching can be achieved with phosphoric acid or self-etching primers (SEPs). Its purpose is to remove the smear layer and to demineralize the dentin to an extent of 2-10 $\mu \mathrm{m} \frac{(59)}{}$. Etchants cause partial removal of peritubular dentin and result in widening of the dentin tubules. Also, they demineralize the intertubular dentin and expose the collagen scaffold ${ }^{(60)}$. Two mechanisms contribute to the resin-to-dentin bond strength: resin tag penetration and resin penetration into the dentin tubules ${ }^{(61)}$. Resin tag penetration is the most important mechanism. It is achieved through the formation of the hybrid layer on the intertubular dentin by penetration, and later polymerization, of the hydrophilic and hydrophobic adhesive monomers into the exposed collagen network $\frac{(60)}{6}$. The presence of some amount of moisture is important during this process because it allows for better penetration of the adhesive monomers in the collagen network and dentin tubules after acid etch treatment $\frac{(62)}{6}$. The presence of a moderate amount of moisture results in superior push-out bond strength and lower nanoleakage $\frac{(63)}{6}$. The second mechanism, penetration into the dentin tubules, results in less retention. The tubules are covered by peritubular dentin, which is approximately $40 \%$ more mineralized than intertubular 
dentin and has less collagen fibers $\frac{(64)}{}$. This results in less successful hybridization $\frac{(61)}{}$. The use of 3-step adhesive systems (etching, primer, and adhesive) is still considered the gold standard for bonding to coronal dentin because they show less marginal defects after 1 year $\underline{(65)}$ and a better marginal seal after 3 years $\stackrel{(66)}{\text {. }}$

Bonded post systems require a successful bond to radicular dentin. Resin bonding to apical radicular dentin could be less strong compared with bonding to cervical radicular and coronal dentin $\underline{67}, \underline{68}, \underline{69}, \underline{70}, \underline{71}$. Cervical radicular dentin is morphologically similar to deep coronal dentin (64), but apical radicular dentin presents important differences. In particular, the number and diameter of dentin tubules gradually decrease toward the root apex $\frac{(72)}{2}$. The tubule number decreases dramatically from approximately 42,360 per $\mathrm{mm}^{2}$ to 8190 per $\mathrm{mm}^{2}$ from the cervical to the apical radicular dentin $\frac{(73)}{}$. This may result in decreased adhesive infiltration in the apical portion (74). Phosphoric acid or SEPs did not change the dentin tubule density; however, the cross-sectional area of the tubules increased significantly after the use of SEPs and even more after the use of phosphoric acid ${ }^{(64)}$. Also, radicular dentin shows convex, dome-shaped irregular projections (calcospherites), which may affect the diffusion of adhesive monomers $\underline{64}$. 75. According to a theoretic model, these differences could lead to a $90 \%$ reduced bond strength to radicular dentin ${ }^{(72)}$. However, it is unclear whether these morphologic differences could be important because some studies found higher bond strengths in the apical third of the post space preparation compared with the middle and cervical third $\underline{76}, \underline{77}$. Other studies found no differences in the bond strength between coronal and radicular dentin $\underset{(78)}{ }$ or between the different portions of radicular dentin $\underline{79}, \underline{80}$.

Procedures related to endodontic treatment, post space preparation, and post cementation may further impact the quality of the post-endodontic adhesive interface. Chemomechanical preparation materials containing peroxides and glycol (RC-Prep [Premier Dental, Plymouth Meeting, PA]) may decrease the bonding capability of resin cements to radicular dentin (81) Residual peroxides may oxidize the dentin collagen network or may further break down into oxygen, inhibiting the polymerization of resin-based products $\frac{(81)}{2}$. Glycol lubricant may be difficult to remove and may inhibit proper monomer polymerization $\stackrel{(81)}{ }$. The use of eugenolbased sealers during endodontic treatment has well-known effects on the bonding to dentin and polymerization of composite resin materials $\underline{77}, \underline{79}, \underline{82}, \underline{83}, \underline{84}, \underline{85}$. The effect of eugenol is also time dependent because it may continue to penetrate the dentin tubules over time ${ }^{(86)}$. During post space preparation, reamers are used to remove gutta-percha (GP), which results in a heat-plasticized smear layer rich in endodontic sealer and GP remnants $\underline{70}, \underline{\mathbf{7}}$. There are no scientific data to suggest that this type of smear layer can be successfully removed by etching. The absence of a chemical bond between the polyisoprene component of GP and the methacrylate component of resin cements may further jeopardize the bond to dentin $(88)$. Etchants may not flow completely in the root canal, causing inadequate exposure of the collagen fibers. Furthermore, etchants cannot be removed completely, and residual etchants may cause low pH-related inhibition of polymerization of resin-based materials $\frac{(89)}{}$. The presence of excessive amounts of moisture is another challenge in the root canal environment $(63,71)$, and voids between posts and root canal walls are evident when resin cements are used $\underline{15}, \underline{90}, \underline{91}, \underline{92}$. Incomplete light penetration in the post space can also result in incomplete polymerization of both the adhesive agent and the resin cement $\underline{93}, \underline{94}$. 
Even if there was successful etching and monomer penetration into the radicular dentin, the geometric characteristics of the configuration of the root canal may not be favorable. The configuration factor (c-factor) was first described for coronal direct restorations using composite resin in $1987 \stackrel{(95)}{2}$. The c-factor can vary from 0.5 to 5 and depends on the ratio of bonded to unbonded surfaces $\stackrel{(95)}{ }$. The root canal simulates a very deep class I cavity in which the c-factor value may exceed that of 200 , resulting in uncontrolled resin polymerization contraction $(96)$. The resulting stress from volumetric shrinkage may exceed the bond strength with radicular dentin $\underline{70}, \underline{97}$.

There are ways to overcome some of the potential problems. Ascorbic acid or sodium ascorbate act as reducing agents and may reverse the negative oxidizing effects of sodium

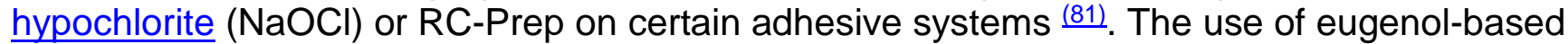
sealers has been limited in favor of resin-based sealers that do not inhibit the polymerization of composite resins $\underline{84}, \underline{85}$. Also, preparation of radicular dentin with chlorhexidine solution or ethanol may improve the durability of the bond when a self-etching system is used $\underline{82}, \underline{98}, \underline{99}$. Chlorhexidine may preserve the bond to radicular dentin even after cyclic loading and when a total etching system is used $\underline{100}, \underline{101}$. Chlorhexidine inhibits degradation caused by dentin matrix

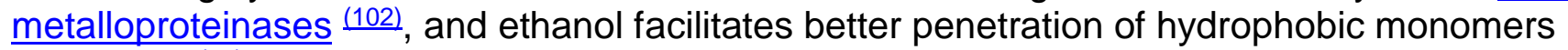
into dentin (98). The use of EDTA and $\mathrm{NaOCl}$ may eliminate the radicular smear layer more efficiently, resulting in improved retentive strength when a self-adhesive resin cement is used $\underline{93}, \underline{99}, \underline{103}, \underline{104}$. However, the oxidizing effect of $\mathrm{NaOCl}$ may not be compatible with all bonding

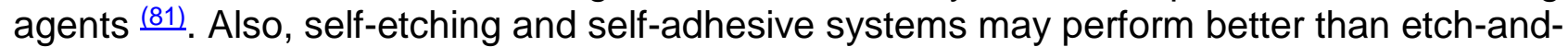
rinse systems in the root canal because they are less sensitive to the moist radicular environment $\underline{71}, \underline{105}, \underline{106}, \underline{107}$. Self-adhesive systems may also result in superior push-out and shear bond strengths of fiber posts and lower polymerization stresses $\underline{37}, \underline{108}, \underline{109}$. However, contradictory results were found in other studies $\underline{34}, \underline{91}$. Intracanal air-drying could be more effective than paper points in the removal of solvents and water, resulting in improved push-out bond strength when a self-etching adhesive is used $\stackrel{(110)}{ }$. In addition, resin cements that create a thin and uniform film around a well-adapted post are less likely to include voids $\underline{90}, \underline{92}$. The use of an injection delivery cement system or a rotary spiral paste filler may also reduce voids and

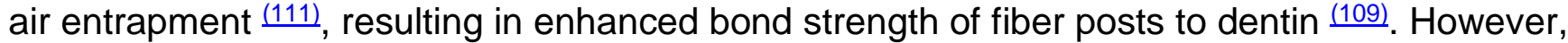
these methods should be used only if indicated by the cement manufacturer. Slow-setting cements have the potential to provide stress relief during polymerization $\underline{112} \underline{113}$. Finally, enhanced light penetration combined with self-activating dual polymerizing adhesives and dual polymerizing resin cements may result in improved polymerization, improved cement properties, and a better bond to dentin $\underline{93}, \underline{94}, \underline{114}, \underline{115}$. Table 2 presents a summary of studies that discuss the bond to radicular dentin.

Table 2. Summary of Studies: Bond to Radicular Dentin

Author(s) Year Materials

Carrigan et al 1984 Evaluation of mean number of dentin tubules (73) in different regions of root dentin and in different age groups

\section{Conclusion(s)}

Mean number of dentin tubules was less in the apical region of the root canal. Mean number of 


\begin{tabular}{|c|c|c|c|}
\hline Author(s) & Year & Materials & $\begin{array}{l}\quad \text { Conclusion(s) } \\
\text { dentin tubules was less in } \\
\text { older individuals. }\end{array}$ \\
\hline $\begin{array}{l}\text { Tjan and } \\
\text { Nemetz } \frac{(82)}{}\end{array}$ & 1992 & $\begin{array}{l}\text { Metallic post cementation with self-etching } \\
\text { system after eugenol contamination: } \\
\text { noncontaminated, water, water/ethanol, } \\
\text { water/ethanol/citric acid, } \\
\text { water/ethanol/acetone, phosphoric } \\
\text { acid/water, zinc phosphate cement/water }\end{array}$ & $\begin{array}{l}\text { Post retention was } \\
\text { decreased when cemented } \\
\text { in the presence of } \\
\text { eugenol. Irrigation with } \\
\text { ethanol restored post } \\
\text { retention. }\end{array}$ \\
\hline $\begin{array}{l}\text { Wakabayashi } \\
\text { et al (75) }\end{array}$ & 1993 & $\begin{array}{l}\text { Evaluation of root canal wall and dentin } \\
\text { tubule arrangement }\end{array}$ & $\begin{array}{l}\text { Appearance of } \\
\text { calcospherites becomes } \\
\text { more frequent toward the } \\
\text { apical portion of the root } \\
\text { canal wall. }\end{array}$ \\
\hline Ngoh et al $\stackrel{(79)}{ }$ & 2001 & $\begin{array}{l}\text { Regional bond strength of } 2 \text { resin cements to } \\
\text { radicular dentin using a eugenol and } \\
\text { noneugenol sealer }\end{array}$ & $\begin{array}{l}\text { Microtensile bond strength } \\
\text { of resin cement was } \\
\text { reduced when a eugenol } \\
\text { sealer was used. }\end{array}$ \\
\hline $\begin{array}{l}\text { Morris et al } \\
(81)\end{array}$ & 2001 & $\begin{array}{l}\text { Resin cement bond to radicular dentin after } \\
\mathrm{NaCl} \text { solution, } \mathrm{NaOCl}, \mathrm{RC}-\mathrm{Prep} \\
\mathrm{NaCl} \text { /ascorbic acid, } \mathrm{NaOCl} \text { ascorbic acid, } \\
\mathrm{NaOCl} / \text { neutral sodium ascorbate, and RC- } \\
\text { Prep/ascorbic acid }\end{array}$ & $\begin{array}{l}\text { Tensile bond strength of } \\
\text { resin cement was reduced } \\
\text { when } \mathrm{NaOCl} \text { or RC-Prep } \\
\text { was used. Negative effects } \\
\text { were reversed with } \\
\text { ascorbic acid or sodium } \\
\text { ascorbate. }\end{array}$ \\
\hline $\begin{array}{l}\text { Bouillaguet } \\
\text { et al (96) }\end{array}$ & 2003 & $\begin{array}{l}\text { Composite resin posts cemented with total } \\
\text { etch, self-etch adhesive systems, or resin- } \\
\text { modified glass ionomer cement, with and } \\
\text { without the effect of configuration factor }\end{array}$ & $\begin{array}{l}\text { Microtensile bond strength } \\
\text { of resin to dentin was less } \\
\text { when cementation was } \\
\text { performed in intact canals } \\
\text { compared with flat } \\
\text { radicular dentin. }\end{array}$ \\
\hline $\begin{array}{l}\text { Serafino et al } \\
(87)\end{array}$ & 200 & $\begin{array}{l}\text { Post space preparation after endodontic } \\
\text { treatment: } \mathrm{NaOCl}, \mathrm{NaOCl} / \mathrm{EDTA}\end{array}$ & $\begin{array}{l}\text { Extensive areas of debris, } \\
\text { GP remnants, and smear } \\
\text { layer were identified in all } \\
\text { regions. }\end{array}$ \\
\hline $\begin{array}{l}\text { Grandini et al } \\
(\underline{90)}\end{array}$ & 200 & $\begin{array}{l}\text { Adhesive cementation of quartz fiber and } \\
\text { experimental anatomic posts }\end{array}$ & $\begin{array}{l}\text { In all groups, voids were } \\
\text { observed within the } \\
\text { cement and between posts } \\
\text { and cement. }\end{array}$ \\
\hline
\end{tabular}




\begin{tabular}{|c|c|c|c|}
\hline Author(s) & Year & Materials & Conclusion(s) \\
\hline $\begin{array}{l}\text { Goracci et al } \\
(91)\end{array}$ & & $\begin{array}{l}\text { Glass fiber posts cemented with total etch } \\
\text { system, self-etch system, or self-adhesive } \\
\text { system }\end{array}$ & $\begin{array}{l}\text { Micro-push-out bond } \\
\text { strength was greater for } \\
\text { the total etch system. }\end{array}$ \\
\hline $\begin{array}{l}\text { Muniz and } \\
\text { Mathias }(77)\end{array}$ & & $\begin{array}{l}\text { Adhesive cementation of fiber posts after } \\
\text { different irrigant and endodontic sealer } \\
\text { combinations: distilled water, } \mathrm{NaOCl}, \mathrm{AH} \\
\text { Plus (Dentsply Maillefer, Tulsa, OK), Endofil } \\
\text { (Promedica Dental Material GmbH, } \\
\text { Neumuenster, Germany) }\end{array}$ & $\begin{array}{l}\text { Micro-push-out bond } \\
\text { strength was reduced } \\
\text { when eugenol-based } \\
\text { sealer was used. Bond } \\
\text { strength values were } \\
\text { greater in the apical } \\
\text { region. }\end{array}$ \\
\hline $\begin{array}{l}\text { Baldi } \\
\text { et al }\end{array}$ & & $\begin{array}{l}\text { Endodontic treatments: distilled water, } \\
\mathrm{NaOCl} / \mathrm{ZOE} \text { sealer, NaOCl/resin sealer, } \\
\mathrm{NaOCl} / \mathrm{EDTA} / \mathrm{ZOE} \text { sealer, } \\
\mathrm{NaOCl/EDTA/resin} \text { sealer, with and without } \\
\text { cycling loading }\end{array}$ & $\begin{array}{l}\text { Micro-push-out bond } \\
\text { strength was reduced } \\
\text { when eugenol-based } \\
\text { sealer was used in cycled } \\
\text { groups. }\end{array}$ \\
\hline $\begin{array}{l}\text { Wrba } \\
(34)\end{array}$ & & $\begin{array}{l}7 \text { Quartz fiber post conditioning methods: } \\
\text { silane, untreated Bonding methods: total } \\
\text { etch, self-etching, self-adhesive }\end{array}$ & $\begin{array}{l}\text { Tensile bond strength was } \\
\text { higher with the use of a } \\
\text { total etch system. }\end{array}$ \\
\hline $\begin{array}{l}\text { Mallman et al } \\
(69)\end{array}$ & 2007 & $\begin{array}{l}7 \text { Two types of quartz fiber posts cemented } \\
\text { with } 2 \text { different adhesive systems }\end{array}$ & $\begin{array}{l}\text { Microtensile bond strength } \\
\text { was less in the apical } \\
\text { region. }\end{array}$ \\
\hline $\begin{array}{l}\text { Perdigao et al } \\
(70)\end{array}$ & 2007 & $\begin{array}{l}7 \text { Quartz fiber posts cemented in post spaces } \\
\text { of varying diameter }\end{array}$ & $\begin{array}{l}\text { Post space diameter did } \\
\text { not affect the bond } \\
\text { strength. }\end{array}$ \\
\hline $\begin{array}{l}\text { Faria } \\
\text { et al }\end{array}$ & & $\begin{array}{l}\text { uartz } \\
\text { ber post }\end{array}$ & $\begin{array}{l}\text { Degree of resin cement } \\
\text { t polymerization conversion } \\
\text { was greater with the } \\
\text { translucent fiber post. }\end{array}$ \\
\hline $\begin{array}{l}\text { Pote } \\
(71)\end{array}$ & & $\begin{array}{l}3 \text { Etching technique after endodontic treatment } \\
\text { and post space preparation: acid gel, } \\
\text { semigel, low-viscosity gel, liquid etchant, and } \\
\text { self-etching primer }\end{array}$ & $\begin{array}{l}\text { Micro-push-out bond } \\
\text { strength of composite resin } \\
\text { was higher when a self- } \\
\text { etching primer was used. }\end{array}$ \\
\hline Wu et al (93) & & $\begin{array}{l}9 \text { Glass fiber post cementation: different } \\
\text { combinations of light-cured self-etching } \\
\text { adhesive, dual-cured self-etching adhesive, } \\
\text { use of light-guiding attachment, } \mathrm{NaOCl}\end{array}$ & $\begin{array}{l}\text { Microtensile bond strength } \\
\text { was higher for posts } \\
\text { cemented with a light- } \\
\text { guiding attachment. NaOCl } \\
\text { further improved bond } \\
\text { strength. }\end{array}$ \\
\hline $\begin{array}{l}\text { Radovic et al } \\
(115)\end{array}$ & 200 & $\begin{array}{l}\text { tation of fiber posts with and without } \\
\text { nsmitting ability }\end{array}$ & $\begin{array}{l}\text { A fiber post with light- } \\
\text { transmitting ability resulted }\end{array}$ \\
\hline
\end{tabular}




\begin{tabular}{|c|c|c|c|}
\hline Author(s) & Year & Materials & $\begin{array}{l}\text { Conclusion(s) } \\
\text { in a more continuous, } \\
\text { harder, and stiffer cement } \\
\text { layer. }\end{array}$ \\
\hline $\begin{array}{l}\text { Caiado et al } \\
(64)\end{array}$ & 2010 & $\begin{array}{l}\text { Evaluation of density and cross-sectional } \\
\text { area of dentin tubules in deep coronal and } \\
\text { radicular dentin after etching treatment }\end{array}$ & $\begin{array}{l}\text { Dentin tubular density was } \\
\text { not affected by acid } \\
\text { treatment. Cross-sectional } \\
\text { area of dentin tubules } \\
\text { increased after acid } \\
\text { treatment. }\end{array}$ \\
\hline $\begin{array}{l}\text { Oliveira et al } \\
\underline{(37)}\end{array}$ & 2011 & $\begin{array}{l}\text { Glass fiber post conditioning methods: silane, } \\
\text { untreated; cemented with self-adhesive } \\
\text { cements or total etch system }\end{array}$ & $\begin{array}{l}\text { Shear bond strength was } \\
\text { higher for posts cemented } \\
\text { with a self-adhesive } \\
\text { system compared with a } \\
\text { total etch system. }\end{array}$ \\
\hline $\begin{array}{l}\text { Manicardi } \\
\text { et al } \underline{(74)}\end{array}$ & & $\begin{array}{l}\text { Quartz fiber posts cemented with different } \\
\text { filling materials: GP/Grossmann sealer, } \\
\text { GP/AH Plus, GP/Epiphany, Resilon/Epiphany } \\
\text { (Pentron Clinical Technologies, LLC, } \\
\text { Wallingford, CT), no filler }\end{array}$ & $\begin{array}{l}\text { Micro-push-out bond } \\
\text { strength was not } \\
\text { influenced by sealer or } \\
\text { region. Coronal region } \\
\text { presented denser resin tag } \\
\text { formations. }\end{array}$ \\
\hline $\begin{array}{l}\text { Cecchin et al } \\
(98)\end{array}$ & & $\begin{array}{l}\text { Post space treatment before self-etching } \\
\text { adhesive cementation: physiologic solution, } \\
\text { chlorhexidine, ethanol, chlorhexidine/ethanol; } \\
\text { storage up to } 12 \text { months }\end{array}$ & $\begin{array}{l}\text { Micro-push out bond } \\
\text { strength of fiber posts was } \\
\text { preserved with } \\
\text { chlorhexidine and/or } \\
\text { ethanol pretreatment. }\end{array}$ \\
\hline $\begin{array}{l}\text { Cecchin et al } \\
(100)\end{array}$ & & $\begin{array}{l}\text { Post space treatment before total etch } \\
\text { adhesive cementation: physiologic solution, } \\
\text { chlorhexidine, ethanol, chlorhexidine/ethanol; } \\
\text { storage up to } 12 \text { months }\end{array}$ & $\begin{array}{l}\text { Micro-push-out bond } \\
\text { strength of fiber posts was } \\
\text { preserved with } \\
\text { chlorhexidine } \\
\text { pretreatment. }\end{array}$ \\
\hline Vichi et al $\stackrel{(94)}{ }$ & & $\begin{array}{l}2 \text { Fiber post cementation: light polymerizing } \\
\text { cement, dual polymerizing cement, with or } \\
\text { without dual polymerizing adhesive }\end{array}$ & $\begin{array}{l}\text { Polymerization was more } \\
\text { effective when a dual } \\
\text { polymerizing adhesive } \\
\text { agent and a dual } \\
\text { polymerizing resin cement } \\
\text { were used. }\end{array}$ \\
\hline $\begin{array}{l}\text { Bergoli et al } \\
(108)\end{array}$ & & $\begin{array}{l}\text { Glass fiber post cementation: total etch } \\
\text { system, self-etching system, phosphoric } \\
\text { acid/self-adhesive cement, self-adhesive } \\
\text { system }\end{array}$ & $\begin{array}{l}\text { Micro-push-out bond } \\
\text { strength was higher, and } \\
\text { polymerization stress was } \\
\text { lower when a self- }\end{array}$ \\
\hline
\end{tabular}




\begin{tabular}{|c|c|c|c|}
\hline Author(s) & Year & Materials & $\begin{array}{l}\text { Conclusion(s) } \\
\text { adhesive system was } \\
\text { used. }\end{array}$ \\
\hline $\begin{array}{l}\text { AlEisa et al } \\
(85)\end{array}$ & 2013 & $\begin{array}{l}3 \text { Endodontic treatment: eugenol-based and } \\
\text { resin-based sealer }\end{array}$ & $\begin{array}{l}\text { Pull-out force of fiber posts } \\
\text { was superior when a resin- } \\
\text { based sealer was used. }\end{array}$ \\
\hline $\begin{array}{l}\text { Aleisa et al } \\
(105)\end{array}$ & 2013 & $\begin{array}{l}3 \text { Glass fiber post cementation with different } \\
\text { adhesive systems }\end{array}$ & $\begin{array}{l}\text { Pull-out force of fiber posts } \\
\text { was greater when a self- } \\
\text { adhesive system was } \\
\text { used. }\end{array}$ \\
\hline $\begin{array}{l}\text { Wang et al } \\
(106)\end{array}$ & 2013 & $\begin{array}{l}3 \text { Glass fiber post cementation: } 3 \text {-step } \\
\text { adhesive, 2-step adhesive, self-etching } \\
\text { adhesive, with or without chlorhexidine } \\
\text { irrigation }\end{array}$ & $\begin{array}{l}\text { Micro-push-out bond } \\
\text { strength of fiber posts was } \\
\text { higher with a self-etching } \\
\text { adhesive system. } \\
\text { Chlorhexidine did not } \\
\text { improve immediate bond } \\
\text { strength. }\end{array}$ \\
\hline $\begin{array}{l}\text { Gomes et al } \\
(92)\end{array}$ & 2014 & $\begin{array}{l}4 \text { Glass fiber post cementation: well adapted, } \\
\text { moderately adapted, poorly adapted }\end{array}$ & $\begin{array}{l}\text { Micro-push-out bond } \\
\text { strength was higher for } \\
\text { well-adapted posts that } \\
\text { formed a thinner cement } \\
\text { layer. }\end{array}$ \\
\hline $\begin{array}{l}\text { Cecchin et al } \\
(101)\end{array}$ & & $\begin{array}{l}4 \text { Post space treatment before adhesive } \\
\text { cementation: physiologic solution, } \\
\text { chlorhexidine, ethanol, chlorhexidine/ethanol }\end{array}$ & $\begin{array}{l}\text { Micro-push-out bond } \\
\text { strength of fiber posts was } \\
\text { preserved with } \\
\text { chlorhexidine and/or } \\
\text { ethanol pretreatment. }\end{array}$ \\
\hline Aziz et al $\underline{(110)}$ & & $\begin{array}{l}4 \text { Solvent removal and polymerization methods } \\
\text { for glass fiber post cementation with self- } \\
\text { etching adhesive: concurrent polymerization } \\
\text { of adhesive and cement, separate } \\
\text { polymerization of adhesive and cement, } \\
\text { intracanal polymerization of adhesive, each } \\
\text { method using paper points or intracanal air } \\
\text { drying for solvent removal }\end{array}$ & $\begin{array}{l}\text { Micro-push-out bond } \\
\text { strength of fiber posts was } \\
\text { higher when solvent was } \\
\text { removed with intracanal air } \\
\text { drying. Polymerization } \\
\text { method did not affect bond } \\
\text { strength. }\end{array}$ \\
\hline $\begin{array}{l}\text { Souza et al } \\
\text { (111) }\end{array}$ & & $\begin{array}{l}\text { Cement delivery for glass fiber post } \\
\text { cementation: on post, Lentulo-type spiral, } \\
\text { explorer, injection delivery system }\end{array}$ & $\begin{array}{l}\text { Micro-push-out bond } \\
\text { strength of fiber posts was } \\
\text { higher, and cement had } \\
\text { less voids with an injection } \\
\text { system. }\end{array}$ \\
\hline
\end{tabular}




\begin{tabular}{|c|c|c|}
\hline Author(s) & Materials & Conclusion(s) \\
\hline $\begin{array}{l}\text { Rezende et al } \\
(63)\end{array}$ & $\begin{array}{l}2016 \text { Glass fiber post cementation: dry, wet, } \\
\text { overwet radicular dentin }\end{array}$ & $\begin{array}{l}\text { Micro-push-out bond } \\
\text { strength was higher when } \\
\text { dentin was wet ( } 5 \text { seconds } \\
\text { air-drying and } 2 \text { paper } \\
\text { points). }\end{array}$ \\
\hline $\begin{array}{l}\text { Aleisa et al } \\
(86)\end{array}$ & $\begin{array}{l}2016 \text { Fiber posts cemented with } 3 \text { different luting } \\
\text { agents, } 24 \text { hours or } 2 \text { weeks after obturation; } \\
\text { endodontic treatment with eugenol-based } \\
\text { sealer }\end{array}$ & $\begin{array}{l}\text { Pull-out force of fiber posts } \\
\text { was reduced when the } \\
\text { post cementation occurred } \\
2 \text { weeks after obturation. }\end{array}$ \\
\hline Kul et al $\stackrel{(103)}{~}$ & $\begin{array}{l}2016 \text { Irrigation procedure before self-adhesive } \\
\text { cementation of glass fiber posts: distilled } \\
\text { water, NaOCl/EDTA, chlorhexidine solution, } \\
\text { phosphoric acid }\end{array}$ & $\begin{array}{l}\text { Micro-push-out bond } \\
\text { strength was higher for } \\
\text { posts when the post space } \\
\text { was irrigated with } \\
\text { NaOCl/EDTA. }\end{array}$ \\
\hline $\begin{array}{l}\text { Pedreira et al } \\
(109)\end{array}$ & $\begin{array}{l}2016 \text { Glass fiber post cementation: self-adhesive } \\
\text { and conventional resin cement; cement } \\
\text { applied using manufacturer's instructions or } \\
\text { an intracanal delivery system }\end{array}$ & $\begin{array}{l}\text { Micro-push-out bond } \\
\text { strength was higher for } \\
\text { fiber posts when a self- } \\
\text { adhesive system was used } \\
\text { with an intracanal delivery } \\
\text { system }\end{array}$ \\
\hline $\begin{array}{l}\text { Simoes et al } \\
(104)\end{array}$ & $\begin{array}{l}2016 \text { Glass fiber post cementation procedure: total } \\
\text { etch system, self-adhesive cement, } \\
\text { EDTA/self-adhesive cement, phosphoric } \\
\text { acid/self-adhesive cement }\end{array}$ & $\begin{array}{l}\text { Micro-push-out bond } \\
\text { strength of fiber posts was } \\
\text { preserved when a self- } \\
\text { adhesive cement with or } \\
\text { without EDTA was used. }\end{array}$ \\
\hline
\end{tabular}

EDTA, Ethylenediaminetetraacetic acid; GP, Gutta-percha; $\mathrm{NaCl}$, Sodium chloride; $\mathrm{NaOCl}$, Sodium hypochlorite; ZOE, Zinc oxide eugenol.

\section{Microleakage and Degradation of Adhesive Systems}

Microleakage is a phenomenon that happens in both adhesive and nonadhesive systems $\underline{116}$, 117, 118 with a gap size of 10-20 $\mu \mathrm{m}$. Microleakage follows nanoleakage, which occurs in nonvisible gaps within the hybrid layer that have an approximate size of 20-100 nm. Nanoleakage may be the result of incomplete polymerization of the adhesive or the presence of nanometric spaces around the collagen fibers that were not completely infiltrated by the adhesive monomers $\underline{119}, \underline{120}$. These phenomena have been identified in teeth restored with fiber posts in which gaps occur between the dentin and the cement and not between the cement and the post surface $\underline{70}, \underline{121}$. However, they are product dependent $\underline{(122)}$.

Microleakage results in the presence of water molecules in the adhesive interfaces. Both composite resin materials and fiber posts absorb water over time through a process called diffusion $\underline{(123)}$. Water uptake occurs rapidly the first 2 weeks and increases for up to 60 days $\underline{124}$, 
$\underline{125}$. Hygroscopic expansion of composite resin materials may partially counteract polymerization shrinkage stress, which potentially causes the cement to fill shrinkage-related voids or porosities $\underline{(126)}$.

Degradation of the endodontic adhesive systems can be chemical or mechanical $\stackrel{(127)}{2}$. Chemical degradation is a direct result of microleakage and is related to the presence of water and enzymes $\frac{(127)}{2}$. These enzymes can cause hydrolysis of resin components, detachment of resin fillers, and hydrolysis of the exposed collagen fibers $\underline{127}, \underline{128}$. Mechanical degradation is related to the forces that an adhesive interface is subjected to while chewing $\frac{(129)}{}$. The materials used in postendodontic adhesive systems exhibit different moduli of elasticity, causing stress concentration at the various interfaces when the endodontically treated tooth is subjected to functional loads $\stackrel{(12)}{2}$. Separation and micromovement between different bonded materials may follow when the adhesive interface degrades $\frac{(130)}{}$. Further leakage and caries are expected as a consequence of micromovement between the components $\frac{(131)}{1}$. In addition, thermal changes occur and can induce further stress through thermal contraction and expansion of the materials at the adhesive interfaces because of differences in the coefficient of thermal expansion $\underline{132}, \underline{133}$. Thus, the chance of failure increases as the number of participating interfaces increases $\underline{134}, \underline{135}, \underline{136}$.

The survival and long-term success of endodontically treated teeth with posts are affected by many different factors. There is no evidence to indicate whether the success in bonding is directly correlated to the clinical success of the treated tooth. However, bonding is necessary when fiber-reinforced posts are used $\stackrel{(11)}{ }$. Despite the unfavorable environment for bonding in the root canal system and the many limitations of the techniques and materials used for bonding, successful clinical outcomes are reported in the literature in teeth restored with posts $\underline{137}, \underline{138}, \underline{139}, \underline{140}$. Furthermore, fiber post placement in anterior teeth may increase fracture resistance and subsequently improve tooth survival, especially when the teeth are structurally compromised $\underline{141}, \underline{142}, \underline{143}, \underline{144}$.

\section{Conclusions}

Adhesive cementation of endodontic posts is a popular treatment option because of improved retention. Although a post-endodontic adhesive interface finds application in the theoretically sound cohesive endodontic units, the bond between the endodontic post and the prepared root canal could be easily jeopardized. There are potential limitations in the development of a predictable bond between composite resin materials and both fiber and metallic posts. Additionally, successful adhesion to radicular dentin may be hindered by factors related to the morphology of the dentinal tissue, the materials used during endodontic treatment, the technique for adhesive cementation of the endodontic post, and the geometric characteristics of the root canal space. Further microleakage and degradation phenomena that occur in the complexity of the oral environment may further compromise the post-endodontic adhesive interface. On the other hand, bonding between the adhesives and the post and between the adhesives and the dentin may be enhanced through various post surface treatments and careful selection of root canal irrigants and adhesives. Table 3 summarizes clinical actions that could result in an enhanced bond to radicular dentin. However, any conclusions should be drawn with caution because there are no clinical studies addressing the bonding potential of 
endodontic posts to radicular dentin. Existing knowledge is vastly based on in vitro studies and a few systematic reviews of in vitro studies. Future clinical studies will provide some guidance in selecting the optimal bonding system for endodontic posts.

Table 3. Factors Potentially Affecting Bond Quality to Radicular Dentin and Suggested Actions

Factors affecting bond quality Endodontic treatment related

Chemomechanical preparation materials containing peroxides and glycol

$\mathrm{NaOCl}$

Eugenol-based sealers

Post space preparation related

Smear layer containing sealer and GP remnants

\section{Post cementation related}

Inadequate etchant removal

Moisture control

Incomplete monomer penetration

Cement voids

Incomplete light penetration, polymerization

\section{Geometric}

Configuration factor, resin polymerization contraction

\section{Suggested actions}

Ascorbic acid/sodium ascorbate may reverse oxidizing effects

Pretreatment with ethanol

Use of resin-based sealers

EDTA and $\mathrm{NaOCl}$ may eliminate the smear layer more efficiently

Use of self-adhesive systems

Radicular dentin should be slightly moist Intracanal air-drying may be more effective than paper points

Self-etch and self-adhesive systems are less sensitive to moisture

Pretreatment with ethanol may allow better monomer penetration

A well-adapted post creates a thinner cement layer with less voids

Use of an injection system or rotary spiral for cement delivery

Use of translucent posts with dual polymerizing adhesives and dual polymerizing resin cements

Self-adhesive systems may result in lower polymerization stress

Slow-setting cements may provide polymerization stress relief

Hygroscopic expansion of resin cements may compensate for shrinkage stresses

\section{Degradation}


Factors affecting bond quality

Dental MMPs

Moduli of elasticity differences

Coefficients of thermal expansion

differences
Suggested actions

Chlorhexidine pretreatment may inhibit MMPrelated degradation

GP, gutta-percha; MMP, matrix metalloproteinase; $\mathrm{NaOCl}$, sodium hypochlorite.

Acknowledgments

The authors thank Mrs. Janet Cheng, Marquette University College of Nursing, for editing the manuscript for language and Mr. Alex Frissell, PhD candidate at the Department of English, Marquette University Klinger College of Arts and Sciences and tutor at Marquette University Norman H. Ott Memorial Writing Center, for revising the manuscript for language and style.

The authors deny any conflicts of interest related to this study.

\section{References}

1 I. Nergiz, P. Schmage, M. Ozcan, et al.Effect of length and diameter of tapered posts on the retention J Oral Rehabil, 29 (2002), pp. 28-34

2 R. Terata, K. Nakashima, M. KubotaEffect of temporary materials on bond strength of resin-modified glass-ionomer luting cements to teeth Am J Dent, 13 (2000), pp. 209-211

3 T. Junge, J.I. Nicholls, K.M. Phillips, et al.Load fatigue of compromised teeth: a comparison of 3 luting cements Int J Prosthodont, 11 (1998), pp. 558-564

4 J.P. Duncan, C.H. PameijerRetention of parallel-sided titanium posts cemented with six luting agents: an in vitro study J Prosthet Dent, 80 (1998), pp. 423-428

5 J.A. Soares, M. Brito-Junior, D.R. Fonseca, et al.Influence of luting agents on time required for cast post removal by ultrasound: an in vitro study J Appl Oral Sci, 17 (2009), pp. 145-149

$6 \mathrm{P}$. Bolhuis, A. de Gee, A. FeilzerThe influence of fatigue loading on the quality of the cement layer and retention strength of carbon fiber post-resin composite core restorations Oper Dent, 30 (2005), pp. 220-227

7 J.R. Pereira, R.A. da Rosa, A.L. do Valle, et al.The influence of different cements on the pull-out bond strength of fiber posts J Prosthet Dent, 112 (2014), pp. 59-63

$8 \mathrm{~J}$. Nissan, Y. Dmitry, D. AssifThe use of reinforced composite resin cement as compensation for reduced post length J Prosthet Dent, 86 (2001), pp. 304-308

9 R.S. Schwartz, J.W. RobbinsPost placement and restoration of endodontically treated teeth: a literature review J Endod, 30 (2004), pp. 289-301

10 D. Dietschi, O. Duc, I. Krejci, et al.Biomechanical considerations for the restoration of endodontically treated teeth: a systematic review of the literature, part II 
(evaluation of fatigue behavior, interfaces, and in vivo studies) Quintessence Int, 39 (2008), pp. 117-129

11 M. Naumann, G. Sterzenbach, M. Rosentritt, et al.Is adhesive cementation of endodontic posts necessary? J Endod, 34 (2008), pp. 1006-1010

12 C.J. Soares, L.H. Raposo, P.V. Soares, et al.Effect of different cements on the biomechanical behavior of teeth restored with cast dowel-and-cores-in vitro and FEA analysis J Prosthodont, 19 (2010), pp. 130-137

13 F.R. Tay, D.H. PashleyMonoblocks in root canals: a hypothetical or a tangible goal J Endod, 33 (2007), pp. 391-398

14 C.J. Cormier, D.R. Burns, P. MoonIn vitro comparison of the fracture resistance and failure mode of fiber, ceramic, and conventional post systems at various stages of restoration J Prosthodont, 10 (2001), pp. 26-36

15 G. Maroulakos, W.W. Nagy, E.D. KontogiorgosFracture resistance of compromised endodontically treated teeth restored with bonded post and cores: an in vitro study J Prosthet Dent, 114 (2015), pp. 390-397

16 L.V. Lassila, J. Tanner, A.M. Le Bell, et al.Flexural properties of fiber reinforced root canal posts Dent Mater, 20 (2004), pp. 29-36

17 M. Ferrari, M.C. Cagidiaco, C. Goracci, et al.Long-term retrospective study of the clinical performance of fiber posts Am J Dent, 20 (2007), pp. 287-291

18 B.J. Rasimick, J. Wan, B.L. Musikant, et al.A review of failure modes in teeth restored with adhesively luted endodontic dowels J Prosthodont, 19 (2010), pp. 639-646

19 F. Mannocci, M. Sherriff, T.F. Watson, et al.Penetration of bonding resins into fibrereinforced composite posts: a confocal microscopic study Int Endod J, 38 (2005), pp. $46-51$

20 A.M. Bell, L.V. Lassila, I. Kangasniemi, et al.Bonding of fibre-reinforced composite post to root canal dentin J Dent, 33 (2005), pp. 533-539

21 I.I. Artopoulou, K.L. O'KeefeMaterials used in prefabricated post and core systems. A review of the literature Tex Dent J, 123 (2006), pp. 358-363

22 S. Grandini, C. Goracci, F. Monticelli, et al.Fatigue resistance and structural characteristics of fiber posts: three-point bending test and SEM evaluation Dent Mater, 21 (2005), pp. 75-82

23 T.M. Lastumaki, L.V. Lassila, P.K. VallittuThe semi-interpenetrating polymer network matrix of fiber-reinforced composite and its effect on the surface adhesive properties J Mater Sci Mater Med, 14 (2003), pp. 803-809

24 M. Ferrari, A. Vichi, F. Mannocci, et al.Retrospective study of the clinical performance of fiber posts Am J Dent, 13 (2000), pp. 9B-13B

25 P. Schmage, F.Y. Cakir, I. Nergiz, et al.Effect of surface conditioning on the retentive bond strengths of fiberreinforced composite posts J Prosthet Dent, 102 (2009), pp. 368-377

26 Z.S. Albashaireh, M. Ghazal, M. KernEffects of endodontic post surface treatment, dentin conditioning, and artificial aging on the retention of glass fiber-reinforced composite resin posts J Prosthet Dent, 103 (2010), pp. 31-39 
27 F. Monticelli, M. Toledano, F.R. Tay, et al.A simple etching technique for improving the retention of fiber posts to resin composites J Endod, 32 (2006), pp. 44-47

28 F. Monticelli, M. Toledano, F.R. Tay, et al.Post-surface conditioning improves interfacial adhesion in post/core restorations Dent Mater, 22 (2006), pp. 602-609

29 M. Yenisey, S. KulunkEffects of chemical surface treatments of quartz and glass fiber posts on the retention of a composite resin J Prosthet Dent, 99 (2008), pp. 38-45

30 M. de Sousa Menezes, E.C. Queiroz, P.V. Soares, et al.Fiber post etching with hydrogen peroxide: effect of concentration and application time J Endod, 37 (2011), pp. 398-402

31 Y.K. Kim, J.S. Son, K.H. Kim, et al.A simple 2-step silane treatment for improved bonding durability of resin cement to quartz fiber post J Endod, 39 (2013), pp. 1287-1290

32 J. Perdigao, G. Gomes, I.K. LeeThe effect of silane on the bond strengths of fiber posts Dent Mater, 22 (2006), pp. 752-758

$33 \mathrm{~F}$. Monticelli, R. Osorio, M. Toledano, et al.Improving the quality of the quartz fiber postcore bond using sodium ethoxide etching and combined silaneladhesive coupling J Endod, 32 (2006), pp. 447-451

34 K.T. Wrbas, M.J. Altenburger, J.F. Schirrmeister, et al.Effect of adhesive resin cements and post surface silanization on the bond strengths of adhesively inserted fiber posts J Endod, 33 (2007), pp. 840-843

35 E. Magni, C. Mazzitelli, F. Papacchini, et al.Adhesion between fiber posts and resin luting agents: a microtensile bond strength test and an SEM investigation following different treatments of the post surface J Adhes Dent, 9 (2007), pp. 195202

36 Y. Choi, A. Pae, E.J. Park, et al.The effect of surface treatment of fiber-reinforced posts on adhesion of a resin-based luting agent J Prosthet Dent, 103 (2010), pp. 362-368

37 A.S. Oliveira, E.S. Ramalho, F.A. Ogliari, et al.Bonding self-adhesive resin cements to glass fibre posts: to silanate or not silanate? Int Endod J, 44 (2011), pp. 759-763

38 A.A. Leme, A.L. Pinho, L. de Goncalves, et al.Effects of silane application on luting fiber posts using self-adhesive resin cement J Adhes Dent, 15 (2013), pp. 269-274

39 A. Rathke, H. Frehse, R. Muche, et al.Durability of fiber post-to-composite bonds achieved by physical vapor deposition and tribochemical silica coating $\mathrm{J}$ Adhes Dent, 16 (2014), pp. 559-565

40 F.W. Machado, M. Bossardi, S. Ramos Tdos, et al.Application of resin adhesive on the surface of a silanized glass fiber-reinforced post and its effect on the retention to root dentin J Endod, 41 (2015), pp. 106-110

41 C. Goracci, O. Raffaelli, F. Monticelli, et al.The adhesion between prefabricated FRC posts and composite resin cores: microtensile bond strength with and without post-silanization Dent Mater, 21 (2005), pp. 437-444

42 A.P. Moraes, R. Sarkis-Onofre, R.R. Moraes, et al.Can silanization increase the retention of glass-fiber posts? A systematic review and meta-analysis of in vitro studies Oper Dent, 40 (2015), pp. 567-580 
43 M. Behr, M. Rosentritt, G. Groger, et al. Adhesive bond of veneering composites on various metal surfaces using silicoating, titanium-coating or functional monomers J Dent, 31 (2003), pp. 33-42

$44 \mathrm{H}$. Kolodney, A.D. Puckett, K. BrownShear strength of laboratory-processed composite resins bonded to a silane-coated nickel-chromium-beryllium alloy J Prosthet Dent, 67 (1992), pp. 419-422

45 P. Moulin, M. Degrange, B. PicardInfluence of surface treatment on adherence energy of alloys used in bonded prosthetics J Oral Rehabil, 26 (1999), pp. 413-421

46 R. Janda, J.F. Roulet, M. Latta, et al.Spark erosion as a metal-resin bonding system Dent Mater, 23 (2007), pp. 193-197

$47 \mathrm{~S}$. Shimoe, N. Tanoue, H. Yanagida, et al.Comparative strength of metal-ceramic and metal-composite bonds after extended thermocycling J Oral Rehabil, 31 (2004), pp. 689-694

$48 \mathrm{~T}$. Ishii, H. Koizumi, T. Yoneyama, et al.Comparative evaluation of thione and phosphate monomers on bonding gold alloy and Ti-6Al-7Nb alloy with tri-nbutylborane initiated resin Dent Mater J, 27 (2008), pp. 56-60

49 H.J. Almilhatti, E.T. Giampaolo, C.E. Vergani, et al.Adhesive bonding of resin composite to various $\mathrm{Ni}-\mathrm{Cr}$ alloy surfaces using different metal conditioners and a surface modification system J Prosthodont, 18 (2009), pp. 663-669

$50 \mathrm{H}$. Yanagida, Y. Taira, S. Shimoe, et al. Adhesive bonding of titanium-aluminumniobium alloy with nine surface preparations and three self-curing resins Eur J Oral Sci, 111 (2003), pp. 170-174

51 A. Radhi, A.S. Juszczyk, R.V. Curtis, et al.Effect of GC METALPRIMER II on bond strength of heat-cured acrylic resin to titanium alloy (Ti-6Al-4V) with two different surface treatments Eur J Prosthodont Restor Dent, 16 (2008), pp. 132-137

$52 \mathrm{I}$. Watanabe, M. Hotta, E. Watanabe, et al.Shear bond strengths of laboratory-cured prosthetic composite to primed metal surfaces Am J Dent, 16 (2003), pp. 401-403

53 Y. Tsuchimoto, Y. Yoshida, A. Mine, et al.Effect of 4-MET- and 10-MDP-based primers on resin bonding to titanium Dent Mater J, 25 (2006), pp. 120-124

54 M. Suzuki, M. Yamamoto, A. Fujishima, et al.Raman and IR studies on adsorption behavior of adhesive monomers in a metal primer for $\mathrm{Au}, \mathrm{Ag}, \mathrm{Cu}$, and $\mathrm{Cr}$ surfaces J Biomed Mater Res, 62 (2002), pp. 37-45

55 A. Abreu, M.A. Loza, A. Elias, et al.Tensile bond strength of an adhesive resin cement to different alloys having various surface treatments J Prosthet Dent, 101 (2009), pp. 107-118

$56 \mathrm{H}$. Yanagida, N. Tanoue, T. Ide, et al.Evaluation of two dual-functional primers and a tribochemical surface modification system applied to the bonding of an indirect composite resin to metals Odontology, 97 (2009), pp. 103-108

$57 \mathrm{~K}$. Yoshida, K. Kamada, M. AtsutaAdhesive primers for bonding cobalt-chromium alloy to resin J Oral Rehabil, 26 (1999), pp. 475-478

$58 \mathrm{C}$. Ohkubo, I. Watanabe, T. Hosoi, et al.Shear bond strengths of polymethyl methacrylate to cast titanium and cobalt-chromium frameworks using five metal primers J Prosthet Dent, 83 (2000), pp. 50-57 
59 D.H. Pashley, Y. Zhang, K.A. Agee, et al.Permeability of demineralized dentin to HEMA Dent Mater, 16 (2000), pp. 7-14

60 N. Nakabayashi, K. Kojima, E. MasuharaThe promotion of adhesion by the infiltration of monomers into tooth substrates J Biomed Mater Res, 16 (1982), pp. 265-273

61 A.J. GwinnettQuantitative contribution of resin infiltration/hybridization to dentin bonding Am J Dent, 6 (1993), pp. 7-9

$62 \mathrm{~J}$. Kanca 3rd, J. SandrikBonding to dentin. Clues to the mechanism of adhesion Am J Dent, 11 (1998), pp. 154-159

63 E.C. Rezende, G.M. Gomes, A.L. Szesz, et al.Effects of dentin moisture on cementation of fiber posts to root canals J Adhes Dent, 18 (2016), pp. 29-34

64 A.C. Caiado, M.F. de Goes, F.J. de Souza-Filho, et al.The effect of acid etchant type and dentin location on tubular density and dimension J Prosthet Dent, 103 (2010), pp. 352-361

65 K.L. Van Landuyt, M. Peumans, S. Fieuws, et al.A randomized controlled clinical trial of a HEMA-free all-in-one adhesive in non-carious cervical lesions at 1 year J Dent, 36 (2008), pp. 847-855

66 A.V. Ritter, H.O. Heymann, E.J. Swift Jr., et al.Clinical evaluation of an all-in-one adhesive in non-carious cervical lesions with different degrees of dentin sclerosis Oper Dent, 33 (2008), pp. 370-378

67 S. Inoue, M.A. Vargas, Y. Abe, et al.Microtensile bond strength of eleven contemporary adhesives to dentin J Adhes Dent, 3 (2001), pp. 237-245

$68 \mathrm{~K}$. Bitter, A.M. KielbassaPost-endodontic restorations with adhesively luted fiberreinforced composite post systems: a review Am J Dent, 20 (2007), pp. 353-360

69 A. Mallmann, L.B. Jacques, L.F. Valandro, et al.Microtensile bond strength of photoactivated and autopolymerized adhesive systems to root dentin using translucent and opaque fiber-reinforced composite posts J Prosthet Dent, 97 (2007), pp. 165-172

70 J. Perdigao, G. Gomes, V. AugustoThe effect of dowel space on the bond strengths of fiber posts J Prosthodont, 16 (2007), pp. 154-164

71 F.L. Potesta, J.C. Broome, S.J. O'Neal, et al.The effect of etching technique on the retention of adhesively cemented prefabricated dowels J Prosthodont, 17 (2008), pp. $445-450$

72 D.H. Pashley, B. Ciucchi, H. Sano, et al.Bond strength versus dentine structure: a modelling approach Arch Oral Biol, 40 (1995), pp. 1109-1118

73 P.J. Carrigan, D.R. Morse, M.L. Furst, et al. A scanning electron microscopic evaluation of human dentinal tubules according to age and location J Endod, 10 (1984), pp. 359-363

74 C.A. Manicardi, M.A. Versiani, P.C. Saquy, et al.Influence of filling materials on the bonding interface of thin-walled roots reinforced with resin and quartz fiber posts J Endod, 37 (2011), pp. 531-537

$75 \mathrm{H}$. Wakabayashi, K. Matsumoto, Y. Nakamura, et al.Morphology of the root canal wall and arrangement of underlying dentinal tubules Int Endod J, 26 (1993), pp. 153-158 
76 B.A. Gaston, L.A. West, F.R. Liewehr, et al.Evaluation of regional bond strength of resin cement to endodontic surfaces J Endod, 27 (2001), pp. 321-324

$77 \mathrm{~L}$. Muniz, P. MathiasThe influence of sodium hypochlorite and root canal sealers on post retention in different dentin regions Oper Dent, 30 (2005), pp. 533-539

78 M.F. Burrow, H. Sano, M. Nakajima, et al.Bond strength to crown and root dentin Am J Dent, 9 (1996), pp. 223-229

79 E.C. Ngoh, D.H. Pashley, R.J. Loushine, et al.Effects of eugenol on resin bond strengths to root canal dentin J Endod, 27 (2001), pp. 411-414

80 R.M. Foxton, M. Nakajima, J. Tagami, et al. Adhesion to root canal dentine using one and two-step adhesives with dual-cure composite core materials J Oral Rehabil, 32 (2005), pp. 97-104

81 M.D. Morris, K.W. Lee, K.A. Agee, et al.Effects of sodium hypochlorite and RC-prep on bond strengths of resin cement to endodontic surfaces J Endod, 27 (2001), pp. 753-757

82 A.H. Tjan, H. NemetzEffect of eugenol-containing endodontic sealer on retention of prefabricated posts luted with adhesive composite resin cement Quintessence Int, 23 (1992), pp. 839-844

83 A.S. Altmann, V.C. Leitune, F.M. CollaresInfluence of eugenol-based sealers on pushout bond strength of fiber post luted with resin cement: systematic review and meta-analysis J Endod, 41 (2015), pp. 1418-1423

84 P. Baldissara, F. Zicari, L.F. Valandro, et al.Effect of root canal treatments on quartz fiber posts bonding to root dentin J Endod, 32 (2006), pp. 985-988

$85 \mathrm{~K}$. AlEisa, Z.N. Al-Dwairi, E. Lynch, et al.In vitro evaluation of the effect of different endodontic sealers on retentive strength of fiber posts Oper Dent, 38 (2013), pp. 539-544

86 K. Aleisa, Z.N. Al-Dwairi, S.A. Alsubait, et al.Pull-out retentive strength of fiber posts cemented at different times in canals obturated with a eugenol-based sealer $\mathrm{J}$ Prosthet Dent, 116 (2016), pp. 85-90

87 C. Serafino, G. Gallina, E. Cumbo, et al.Surface debris of canal walls after post space preparation in endodontically treated teeth: a scanning electron microscopic study Oral Surg Oral Med Oral Pathol Oral Radiol Endod, 97 (2004), pp. 381-387

88 M. Hammad, A. Qualtrough, N. SilikasThree-dimensional evaluation of effectiveness of hand and rotary instrumentation for retreatment of canals filled with different materials J Endod, 34 (2008), pp. 1370-1373

89 F. Monticelli, R. Osorio, C. Mazzitelli, et al.Limited decalcification/diffusion of selfadhesive cements into dentin J Dent Res, 87 (2008), pp. 974-979

90 S. Grandini, C. Goracci, F. Monticelli, et al.SEM evaluation of the cement layer thickness after luting two different posts J Adhes Dent, 7 (2005), pp. 235-240

91 C. Goracci, F.T. Sadek, A. Fabianelli, et al.Evaluation of the adhesion of fiber posts to intraradicular dentin Oper Dent, 30 (2005), pp. 627-635

92 G.M. Gomes, E.C. Rezende, O.M. Gomes, et al.Influence of the resin cement thickness on bond strength and gap formation of fiber posts bonded to root dentin J Adhes Dent, 16 (2014), pp. 71-78 
$93 \mathrm{H}$. Wu, M. Hayashi, K. Okamura, et al.Effects of light penetration and smear layer removal on adhesion of post-cores to root canal dentin by self-etching adhesives Dent Mater, 25 (2009), pp. 1484-1492

94 A. Vichi, M. Carrabba, C. Goracci, et al.Extent of cement polymerization along dowel space as a function of the interaction between adhesive and cement in fiber post cementation J Adhes Dent, 14 (2012), pp. 51-57

95 A.J. Feilzer, A.J. De Gee, C.L. DavidsonSetting stress in composite resin in relation to configuration of the restoration J Dent Res, 66 (1987), pp. 1636-1639

96 S. Bouillaguet, S. Troesch, J.C. Wataha, et al.Microtensile bond strength between adhesive cements and root canal dentin Dent Mater, 19 (2003), pp. 199-205

97 F.R. Tay, R.J. Loushine, P. Lambrechts, et al.Geometric factors affecting dentin bonding in root canals: a theoretical modeling approach J Endod, 31 (2005), pp. 584-589

98 D. Cecchin, J.F. de Almeida, B.P. Gomes, et al.Effect of chlorhexidine and ethanol on the durability of the adhesion of the fiber post relined with resin composite to the root canal J Endod, 37 (2011), pp. 678-683

$99 \mathrm{~S}$. Saker, M. OzcanRetentive strength of fiber-reinforced composite posts with composite resin cores: Effect of remaining coronal structure and root canal dentin conditioning protocols J Prosthet Dent, 114 (2015), pp. 856-861

100 D. Cecchin, J.F. de Almeida, B.P. Gomes, et al.Influence of chlorhexidine and ethanol on the bond strength and durability of the adhesion of the fiber posts to root dentin using a total etching adhesive system J Endod, 37 (2011), pp. 1310-1315

101 D. Cecchin, M. Giacomin, A.P. Farina, et al.Effect of chlorhexidine and ethanol on push-out bond strength of fiber posts under cyclic loading J Adhes Dent, 16 (2014), pp. 87-92

102 J. Santos, M. Carrilho, T. Tervahartiala, et al.Determination of matrix metalloproteinases in human radicular dentin J Endod, 35 (2009), pp. 686-689

103 E. Kul, K.Y. Yeter, L.I. Aladag, et al.Effect of different post space irrigation procedures on the bond strength of a fiber post attached with a self-adhesive resin cement $\mathrm{J}$ Prosthet Dent, 115 (2016), pp. 601-605

104 T.C. Simoes, I. Luque-Martinez, R.R. Moraes, et al.Longevity of bonding of selfadhesive resin cement to dentin Oper Dent, 4 (2016), pp. 64-72

105 K. Aleisa, Z.N. Al-Dwairi, R. Alghabban, et al.Effect of luting agents on the tensile bond strength of glass fiber posts: an in vitro study J Prosthet Dent, 110 (2013), pp. 216222

106 L. Wang, T.A. Pinto, L.M. Silva, et al.Effect of $2 \%$ chlorhexidine digluconate on bond strength of a glass-fibre post to root dentine Int Endod J, 46 (2013), pp. 847-854

107 R. Sarkis-Onofre, J.A. Skupien, M.S. Cenci, et al.The role of resin cement on bond strength of glass-fiber posts luted into root canals: a systematic review and metaanalysis of in vitro studies Oper Dent, 39 (2014), pp. 31-44

108 C.D. Bergoli, M. Amaral, L.C. Boaro, et al.Fiber post cementation strategies: effect of mechanical cycling on push-out bond strength and cement polymerization stress J Adhes Dent, 14 (2012), pp. 471-478 
109 A.P. Pedreira, P.H. D'Alpino, P.N. Pereira, et al.Effects of the application techniques of self-adhesive resin cements on the interfacial integrity and bond strength of fiber posts to dentin J Appl Oral Sci, 24 (2016), pp. 437-446

110 T.M. Aziz, M.N. Anwar, F.S. El-AskaryPush-out bond strength of fiber posts to root canal dentin using a one-step self-etching adhesive: the effect of solvent removal and light-curing methods J Adhes Dent, 16 (2014), pp. 79-86

111 A.C. Souza, C. Goncalves Fde, L.C. Anami, et al.Influence of insertion techniques for resin cement and mechanical cycling on the bond strength between fiber posts and root dentin J Adhes Dent, 17 (2015), pp. 175-180

112 C. Goracci, A.U. Tavares, A. Fabianelli, et al.The adhesion between fiber posts and root canal walls: comparison between microtensile and push-out bond strength measurements Eur J Oral Sci, 112 (2004), pp. 353-361

113 C. Goracci, A. Fabianelli, F.T. Sadek, et al.The contribution of friction to the dislocation resistance of bonded fiber posts J Endod, 31 (2005), pp. 608-612

114 A.L. Faria e Silva, V.G. Arias, L.E. Soares, et al.Influence of fiber-post translucency on the degree of conversion of a dual-cured resin cement J Endod, 33 (2007), pp. 303305

115 I. Radovic, G. Corciolani, E. Magni, et al.Light transmission through fiber post: The effect on adhesion, elastic modulus and hardness of dual-cure resin cement Dent Mater, 25 (2009), pp. 837-844

116 H.M. Fogel, M.D. PeikoffMicroleakage of root-end filling materials J Endod, 27 (2001), pp. $456-458$

117 A.H. Tjan, B.E. Grant, J.R. DunnMicroleakage of composite resin cores treated with various dentin bonding systems J Prosthet Dent, 66 (1991), pp. 24-29

118 W.S. Bachicha, P.M. DiFiore, D.A. Miller, et al.Microleakage of endodontically treated teeth restored with posts J Endod, 24 (1998), pp. 703-708

119 H. Sano, T. Takatsu, B. Ciucchi, et al.Nanoleakage: leakage within the hybrid layer Oper Dent, 20 (1995), pp. 18-25

120 M. Okuda, P.N. Pereira, M. Nakajima, et al.Long-term durability of resin dentin interface: nanoleakage vs. microtensile bond strength Oper Dent, 27 (2002), pp. 289-296

$121 \mathrm{~V}$. Santos, J. Perdigao, G. Gomes, et al.Sealing ability of three fiber dowel systems J Prosthodont, 18 (2009), pp. 566-576

122 G. Marchesi, A. Mazzoni, G. Turco, et al.Aging affects the adhesive interface of posts luted with self-adhesive cements: a 1-year study J Adhes Dent, 15 (2013), pp. 173180

123 J.L. FerracaneHygroscopic and hydrolytic effects in dental polymer networks Dent Mater, 22 (2006), pp. 211-222

124 A.M. Diaz-Arnold, M.A. Arnold, V.D. WilliamsMeasurement of water sorption by resin composite adhesives with near-infrared spectroscopy J Dent Res, 71 (1992), pp. 438-442

$125 \mathrm{~J}$. Chai, Y. Takahashi, K. Hisama, et al.Water sorption and dimensional stability of three glass fiber-reinforced composites Int J Prosthodont, 17 (2004), pp. 195-199 
126 E. Moreira da Silva, G.O. dos Santos, J.G. Guimaraes, et al.The influence of C-factor, flexural modulus and viscous flow on gap formation in resin composite restorations Oper Dent, 32 (2007), pp. 356-362

127 F.L. Amaral, V. Colucci, R.G. Palma-Dibb, et al.Assessment of in vitro methods used to promote adhesive interface degradation: a critical review J Esthet Restor Dent, 19 (2007), pp. 340-353 discussion 54

128 C.K. Yiu, N.M. King, D.H. Pashley, et al.Effect of resin hydrophilicity and water storage on resin strength Biomaterials, 25 (2004), pp. 5789-5796

129 J. De Munck, K. Van Landuyt, M. Peumans, et al.A critical review of the durability of adhesion to tooth tissue: methods and results J Dent Res, 84 (2005), pp. 118-132

130 R.C. Fraga, B.T. Chaves, G.S. Mello, et al.Fracture resistance of endodontically treated roots after restoration J Oral Rehabil, 25 (1998), pp. 809-813

131 S.M. Morgano, S.E. BrackettFoundation restorations in fixed prosthodontics: current knowledge and future needs J Prosthet Dent, 82 (1999), pp. 643-657

132 M.S. Gale, B.W. DarvellThermal cycling procedures for laboratory testing of dental restorations J Dent, 27 (1999), pp. 89-99

133 G.A. Crim, F. Garcia-GodoyMicroleakage: the effect of storage and cycling duration J Prosthet Dent, 57 (1987), pp. 574-576

134 P.J. Plasmans, L.G. Visseren, M.M. Vrijhoef, et al.In vitro comparison of dowel and core techniques for endodontically treated molars J Endod, 12 (1986), pp. 382-387

135 A.S. Fernandes, S. Shetty, I. CoutinhoFactors determining post selection: a literature review J Prosthet Dent, 90 (2003), pp. 556-562

136 S. Belli, O. Eraslan, G. Eskitascioglu, et al.Monoblocks in root canals: a finite elemental stress analysis study Int Endod J, 44 (2011), pp. 817-826

137 Y.L. Ng, V. Mann, K. GulabivalaA prospective study of the factors affecting outcomes of nonsurgical root canal treatment: part 1: periapical health Int Endod J, 44 (2011), pp. 583-609

138 J. Juloski, G.M. Fadda, F. Monticelli, et al.Four-year survival of endodontically treated premolars restored with fiber posts J Dent Res, 93 (2014), pp. 52S-58S

139 M. Raedel, C. Fiedler, S. Jacoby, et al.Survival of teeth treated with cast post and cores: a retrospective analysis over an observation period of up to 19.5 years J Prosthet Dent, 114 (2015), pp. 40-45

140 E. Cloet, E. Debels, I. NaertControlled clinical trial on the outcome of glass fiber composite cores versus wrought posts and cast cores for the restoration of endodontically treated teeth: a 5-year follow-up study Int J Prosthodont, 30 (2017), pp. $71-79$

141 J.T. Mangold, M. KernInfluence of glass-fiber posts on the fracture resistance and failure pattern of endodontically treated premolars with varying substance loss: an in vitro study J Prosthet Dent, 105 (2011), pp. 387-393

142 S.J. Schmoldt, T.C. Kirkpatrick, R.E. Rutledge, et al.Reinforcement of simulated immature roots restored with composite resin, mineral trioxide aggregate, guttapercha, or a fiber post after thermocycling J Endod, 37 (2011), pp. 1390-1393 
143 J.G. Phebus, B.M. Owens, W. de Rijk, et al.Fracture resistance of permanent anterior incisors using fiber-reinforced composite posts Gen Dent, 62 (2014), pp. 37-42

144 M. Abduljawad, A. Samran, J. Kadour, et al.Effect of fiber posts on the fracture resistance of maxillary central incisors with class III restorations: an in vitro study J Prosthet Dent, 118 (2017), pp. 55-60 